BULLETIN Bulletin hispanique

HISPANIQUE Université Michel de Montaigne Bordeaux

118-2 | 2016

Varia

\title{
«Que más parecía casa de título que de particular»
}

Actores y pintura en el Madrid del Siglo de Oro

María A. Flórez

\section{CpenEdition}

Journals

Edición electrónica

URL: http://journals.openedition.org/bulletinhispanique/4633

DOI: 10.4000/bulletinhispanique.4633

ISSN: 1775-3821

Editor

Presses universitaires de Bordeaux

Edición impresa

Fecha de publicación: 15 diciembre 2016

Paginación: 647-672

ISBN: 979-10-300-0125-9

ISSN: 0007-4640

Referencia electrónica

María A. Flórez, « «Que más parecía casa de título que de particular» », Bulletin hispanique [En línea], 118-2 | 2016, Publicado el 15 diciembre 2019, consultado el 31 diciembre 2019. URL : http:// journals.openedition.org/bulletinhispanique/4633; DOI : 10.4000/bulletinhispanique.4633 


\title{
"Que más parecía casa de título que de particular». Actores y pintura en el Madrid del Siglo de Oro
}

\author{
María A. Flórez \\ IES Isabel la Católica - Madrid
}

Le fait de posséder des tableaux est la marque évidente d'un certain niveau de vie: celui de quelques comédiens de qualité, tout particulièrement ceux qui se produisaient à la Cour. Les acteurs qui résidaient à Madrid, fiers de leur métier, en vinrent à créer un véritable groupe intellectuel, doté d'une notable influence sociale et faisant partie d'une nouvelle classe moyenne «illustrée » dans laquelle il était de bon ton de posséder des œuvres d'art garantes de leurs connaissances artistiques.

Mots-clés : acteurs, tableaux, Madrid, XVII' siècle, Siècle d'Or.

La posesión de pinturas constituye un claro indicativo del acomodado nivel de vida alcanzado por algunos miembros de la profesión cómica, especialmente por aquellos que representaban habitualmente ante los reyes y la corte. Orgullosos de su oficio, los actores residentes en Madrid constituyeron un grupo intelectual con notoria influencia social que formaba parte de una nueva clase intermedia e «ilustrada» para la que demostrar conocimientos artísticos era señal de prestigio, siendo la posesión de cuadros su consecuencia natural.

Palabras claves: actores, cuadros, Madrid, siglo XVII, Siglo de Oro.

Being the owner of a painting was a clear indication of the high standard of living reached by some members of the acting profession, especially those who performed before kings and the court. Being proud of their profession, resident actors in Madrid were part of an intellectual group, with a marked social influence and making up a new intermediate, enlightened class for which the demonstration of artistic knowledge was good manners, the possession of paintings being a natural consequence of it.

Keywords: Actors, pictures, Madrid, seventeenth century, Golden Century. 
Tos embargos de bienes ordenados por la Junta del Corpus de Madrid L para asegurar la presencia en la villa y corte de los mejores actores de la época, junto con los recibos de dote, nos permiten observar cómo las pinturas ocupaban en muchos casos una proporción nada desdeñable dentro del patrimonio de autores, actores y actrices. Sin embargo, pese a la frecuencia con la que aparecen, los cuadros que adornaban de forma habitual las casas de los actores del siglo XVII no han despertado hasta la fecha el interés de los investigadores del teatro y la pintura, lo cual resulta llamativo dada la estrecha relación existente entre ambas artes en el Siglo de Oro, que sí ha merecido numerosos estudios. En el caso de los profesionales del teatro, éstos se limitan a los dramaturgos, especialmente a Lope de Vega y Calderón, mientras que la relación de los actores con la pintura y los pintores ${ }^{1}$ apenas ha sido estudiada pese a reconocer la importancia que tenía para los miembros de ambas profesiones la representación correcta de la «propiedad de las acciones».

Como es bien sabido, a finales del siglo XVI el arte del gesto («hablar de mano») estaba ya bastante codificado y era, además, muy apreciado socialmente por lo que cualquier persona bien educada debía conocerlo y practicarlo. El dominio de los gestos era también parte esencial de la técnica del actor ${ }^{2}$, obligado por el «decoro» a considerar el estado y edad del personaje que debía representar. Este lenguaje gestual abarcaba «...no solo la expresión del rostro, sino el ademán y movimiento de todo el cuerpo...» ${ }^{3}$. Según López Pinciano «ademán» era «... aquel movimiento que hace el actor con el cuerpo, pies, brazos, ojos y boca, cuando habla, y aun cuando calla algunas veces..." ${ }^{4}$, todo ello debidamente arropado por el «ornato" que era tanto la "compostura del teatro» como de «la persona». Apariencia y gestualidad eran también esenciales para el pintor quien, mediante lo que Palomino denomina «metáfora vultosa» (cap. VII.vii), debía saber representar por las indicaciones del semblante «las pasiones, que ocultamente predominan en los sujetos» y mediante la «acción» (cap. VIII. ii) la «actitud, postura o movimiento en cada figura, más proporcionado a la expresión del asunto» ${ }^{5}$. A todo ello los actores debían ańadir el dominio de la

1. Sobre el posible interés profesional de Velázquez por el arte histriónico, ver María Asunción Flórez Asensio, «Diego Velázquez y Cosme Pérez: Genio e ingenio en la corte de Felipe IV», Madrid, revista de arte, geografía e historia, no 2, 1999, pp. 217-253.

2. Ver Juan Manuel Rozas, «Sobre la técnica del actor barroco», en II Jornadas de Teatro Clásico Español, Almagro, Festival de Almagro, 1979, pp. 90-106; Evangelina Rodríguez Cuadros, La técnica del actor español en el Barroco. Hipótesis y documentos, Madrid, Castalia, 1998; María Asunción Flórez, Música teatral en el Madrid de los Austrias durante el Siglo de Oro, Madrid, ICCMU, 2006, pp. 385-402.

3. Julián Gállego, Visión y simbolos de la pintura española del Siglo de Oro, Madrid, Cátedra, 1984, p. 76.

4. Más adelante, el Pinciano describe toda una serie de ademanes a realizar por el actor mediante las distintas partes del cuerpo: pies, manos, dedos, ojos y cabeza. Alonso López Pinciano, Philosophia Antigua Poética (1595). Cito por la edición de José Rico Verdú, Madrid, Biblioteca Castro, 1998, pp. 522 y 527-529.

5. Antonio Palomino, El museo pictórico y escala óptica (Tomo I), Madrid, 1715. Ver Francisco Calvo Serraller, Teoría de la Pintura del Siglo de Oro, Madrid, Cátedra, 1991, pp. 619-699. 
voz, como demuestran las críticas que abarcan tanto «la tosca pronunciación» y «el errado consonante» como «las acciones afectadas,/los prohibidos meneos/.../ y los mal formados gestos» ${ }^{6}$.

En la mentalidad de la época existía, por tanto, una estrecha vinculación entre pintura y teatro dado que, además de compartir un lenguaje similar, se consideraba que su unión aumentaba el efecto persuasivo de ambos; y si en el teatro cortesano y religioso la escenografía -junto con la música- ocupa un papel relevante como complemento retórico del texto ${ }^{7}$, en las obras destinadas a los corrales los cuadros aparecen mencionados constantemente en relación con los personajes y también con la propia trama. En este último caso es relativamente frecuente la utilización de determinadas pinturas para explicar, anticipar o ampliar el argumento, en lo que constituye una técnica idéntica al recurso del cuadro dentro del cuadro ${ }^{8}$ de la que se apropia igualmente el propio teatro al crear dentro del escenario otros espacios con su propia iluminación y escenografía?. Por lo que se refiere a los personajes, sus aficiones artísticas (pintores, iconografías y calidad estética) «...constituye una clave para comprender su carácter...» y "...sirve para caracterizarlo moralmente...» ${ }^{10}$. A lo que se ańade que, para describir sus sentimientos, muchos personajes de comedia aluden a temas representados frecuentemente en las pinturas, clara señal de su popularidad entre el público y cuyo significado los actores no podían desconocer, como tampoco podían ignorar que, además de por su calidad artística, la pintura de la época se apreciaba tanto por lo que contaba como por cómo lo contaba ya que el mismo principio se aplicaba a su propio arte. Pero aunque la técnica del actor exigía tanto el dominio de la voz como de los gestos y de la propia apariencia según las reglas del «decoro», no eran muchos los que suscitaban elogios tan encendidos como los que el padre Alcázar dedica a Damián Arias de Peñafiel: «Dijera lo que dijera, en cada movimiento de la lengua parece que tenía las gracias y en cada movimiento de la mano la

6. Sátira contra los representantes de la compañia de Juan de Morales Medrano. Ver en Flórez, op. cit. p. 392.

7. Ver Javier Portús Pérez, Pintura y pensamiento en la España de Lope de Vega, Guipúzcoa, Nerea, 1999, p. 44. Debido a la importancia que va a ir adquiriendo la escenografía, Calderón encomienda a la música la tarea de restablecer el equilibrio entre lo visual y lo auditivo. Ver Flórez, op. cit, p. 491.

8. Portús Pérez, op. cit., p. 175.

9. Ese sería el caso de la cueva, gruta o prisión, tan habitual en el teatro de Calderón, que contribuye a «...crear un teatro dentro del propio escenario y ampliar perspectivas con una iluminación y un fondo diferentes». Aurora Egido, "Introducción» a su edición de La fiera, el rayo y la piedra de Pedro Calderón de la Barca, Madrid, Cátedra, 1989, pp. 11-121, p. 37.

10. Portús Pérez, op. cit., pp. 174-175 y 184. Para la posible influencia del tratado de Francisco Pacheco en los retratos pintados en escena en el teatro de la época ver Lygia Rodrigues Vianna Peres, «El retrato y El Arte de la Pintura de Francisco Pacheco en obras del teatro del Siglo de Oro», en C. Mata y M. Zugasti (eds.). Actas del congreso El Siglo de Oro en el nuevo milenio, 2 vols, Pamplona, Eunsa, 2005, vol. II, pp. 1477-1490. 
musa» ${ }^{11}$, convertido por ello en modelo no sólo para sus propios compañeros sino también para predicadores y oradores profesionales.

Semejante a la de malos actores y pésimos poetas era la proliferación de malos pintores, por lo que en la España del siglo XVII no resultaba difícil encontrar en el mercado un amplio surtido de lienzos mediocres e, incluso, de bajísima calidad. La mayoría eran de tema religioso debido a su mayor demanda al cubrir las necesidades devocionales de las capas medias de la época, pero sin excluir las pinturas mitológicas, los países, floreros, bodegones o naturalezas muertas, retratos y copias de cuadros célebres. Muchos pintores de segunda y tercera fila tenían abierta tienda para la venta de sus cuadros y de los ajenos, que se podían comprar también en otras regentadas por tratantes de pinturas, e incluso a vendedores ambulantes, como el humilde pintor retratado por Antolinez (fig. 1, p. 658). En torno a la calle Mayor, la zona comercial más importante de la villa, se situaban numerosas tiendas de pintura, concentrándose muchas de ellas en la calle de Santiago «...llena de tiendas de malísimos pintores [...] [donde] se halla[ban] con tanta abundancia Imágenes de Cristo Señor nuestro, de la Santísima Virgen, y de toda clase de santos y santas» ${ }^{12}$. La existencia de estas tiendas redundaba en descrédito de la pintura y los pintores hasta el punto de que, según Palomino, la deshonra que supuso para el pintor Juan de Alfaro «...verse sin tener que pintar, para mantener sus obligaciones; y que habiendo hecho la diligencia de buscarlo en las tiendas de pintura (que entonces había muchas, que hasta a esto se humilló) aún no se pudo hallar, se melancolizó mucho; y tanto, que después se agravó de suerte su dolencia, que a pocos días acabó con él»" ${ }^{13}$. Lo cierto es que supuso un lastre para el reconocimiento de la pintura como arte liberal ${ }^{14}$, mientras que los actores vieron reconocida su profesión como tal desde fechas muy tempranas incluso por detractores del teatro como Fr. Juan de Pineda, quien admite que el oficio es arte y "no deja de requerir hombres de buen entendimiento» ${ }^{15}$. Son las "circunstancias y adherencias» las que han «...hecho infame este oficio no ha sido él en su naturaleza que, pues es arte, es noble como lo son todas las artes

11. José Alcázar, Ortografía castellana (c. 1690). Ver en Federico Sánchez Escribano y Alberto Porqueras Mayo, Preceptiva dramática española en el Renacimiento y el Barroco, Madrid, Gredos, 1971 , p. 335.

12. J. Interián de Ayala, El pintor Christiano y Erudito (Madrid, 1782). Cito por Miguel Morán Turina, «Aquí fue Troya (de buenas y malas pinturas, de algunos entendidos y otros que no lo eran tanto)», en Miguel Morán Turina y Javier Portús Pérez, El arte de mirar. La pintura y su público en la España de Velázquez, Madrid, Istmo, 1997, pp. 93-116, pp. 111-112.

13. Antonio Palomino, «El Parnaso Español Pintoresco Laureado», en Museo Pictórico y escala óptica, III, (Madrid, 1724). Cito por la edición de Nina Ayala Mallory, Antonio Palomino. Vidas, Madrid, Alianza, 1986, p. 264. El subrayado en cursiva es mío.

14. Julián Gállego, El pintor de artesano a artista, Granada, Universidad de Granada, 1976; Juan J. Martín González, El artista en la sociedad española del siglo XVII, Madrid, Cátedra, 1984.

15. Fr. Juan de Pineda, Primera parte de los Treynta y cinco diálogos familiares de la Agricultura Christiana (Salamanca, 1581). Ver en Emilio Cotarelo y Mori, Bibliografia de las controversias sobre la licitud del teatro en España, Madrid, Tip. Rev. De Archivos, Bibl. y Museos, 1904, pp. 503-506; 506. 
liberales; sino el daño le ha venido de las circunstancias, cuales son ser la gente vil y mercenaria, los vicios en que andan envueltos, el representar cosas torpes e infames» ${ }^{16}$. Dado que los ataques de los moralistas no sólo no cesaron, sino que se hicieron aún más virulentos a finales del XVII, a principios del nuevo siglo el Patriarca de las Indias informa al nuevo monarca de cómo

El arte, Señor, de Comediante (así le llama el derecho) [...] por la modestia con que se ejecuta en España está estimado por decente, y honesto, a diferencia de los histriones de la gentilidad; y así en la censura de el derecho, y practica de el Reino son admitidos a la sucesión de Mayorazgos, aunque tengan anexas Dignidad; a la de Beneficios cuando son presentados, o les tocan por derecho de sangre; para ponerse hábitos no ha obstado el haber sido comediante de que hay ejemplares en Madrid, como también que habiendo comediantes actuales sido presos por deudas, y justificado ser nobles, por ejecutoria de los tribunales superiores se ha mandado sean sueltos, calificando en estas decisiones, aun no perderse la nobleza en el ejercicio de este Arte, como en el de los oficios mecánicos ${ }^{17}$.

Las críticas de los moralistas a todos aquellos que por interés «vil y mercenario» ejercían la profesión cómica estaban motivadas en gran parte por la influencia que éstos ejercían sobre el público desde las tablas. De hecho, en la España del siglo XVII la fuerte vinculación económica de la organización teatral con la beneficencia ${ }^{18}$, así como la estrecha relación del teatro profesional con el teatro religioso mediante la representación anual de autos sacramentales, facilitaron la integración social de los actores que desde el último cuarto del siglo XVI aparecen ya como un grupo profesional cohesionado con una confortable situación social ${ }^{19}$ que nada tenía que ver con la marginación que pudieron sufrir en otros países europeos; es más, fue considerada como un modelo a conseguir por los profesionales de países teatralmente tan desarrollados como la propia Italia, en la que el sistema español era bien conocido por haberse implantado también en Milán y Nápoles, ciudades ambas vinculadas a la Monarquía Hispánica. Esto fue así, sobre todo, en el caso de aquellos que actuaban en la corte madrileńa. En tanto que residencia habitual del monarca,

16. «Diálogo 5». En: Diálogos de las comedias (c. 1626) (Anónimo). Ver en Cotarelo y Mori, Bibliografía de las controversias..., pp. 210-231, 222. Ver también Flórez, op. cit., p. 389.

17. Memorial del Patriarca de las Indias a Felipe V (25 de enero de 1707). Biblioteca Nacional (BN). Madrid, Mss. 14.004/6 (fo 11). Modernizo la ortografía de todos los documentos citados. Ver Flórez Asensio María Asunción, «Músicos de las compañías teatrales de Madrid ante el cambio dinástico», en Capdepón Verdú Paulino y Pastor Comín Juan J. (eds.), Sebastián Durón (1660-1716) y la música de su época, Vigo, Editorial Academia del Hispanismo, 2013, pp. 307326.

18. Sólo en Madrid los dos teatros públicos (la Cruz y el Príncipe) sostenían seis hospitales: General, Pasión, Niños Expósitos, Nińos Desamparados o Colegio de Amor de Dios, Real de Corte o del Buen Suceso y Hospital de Antón Martín o de San Juan de Dios.

19. Los actores «...constituyeron un particular grupo social de alta profesionalidad, excelentemente organizado y respetado por amplios círculos de la sociedad... ». Josef Oehrlein, «El actor en el Siglo de Oro: imagen de la profesión y reputación social», en José Ma Diez Borque (ed.), Actor y técnica de representación del teatro clásico español, Londres, Támesis, 1989, pp. 17 33, p. 33. 
Madrid se mantendrá como centro teatral de primer orden durante todo el siglo XVII, convirtiéndose en ámbito preferente de la vida profesional de los autores, actores y actrices de mayor relevancia y prestigio. La mayoría tendrán en ella sus domicilios habituales, asentándose con preferencia en el llamado «barrio del Mentidero", un barrio teatral por excelencia al ubicarse en él los dos corrales de la villa y cercano, además, al Coliseo del Buen Retiro, un teatro de corte que funcionaba también como teatro público ${ }^{20}$. No resulta por ello extraño que en 1694 las principales actrices de la época viviesen en el triángulo formado por la calle Atocha, la de Huertas y el Paseo del Prado: en "casas propias» situadas en la «...calle de Atocha enfrente del hospital real de la pasión...» vivía Eufrasia María de Reina, $1^{\text {a }}$ dama de la compañía de Damián Polop. También en la calle Atocha, pero de alquiler, vivía Águeda Francisca (2a dama de Polop en 1693); Josefa Laura ( $2^{\text {a }}$ dama de Polop ese año) vivía en la calle de Santa María; Josefa de Cisneros, sobresaliente en la misma compañía, en la de Cantarranas (hoy Lope de Vega), y Ángela de San Román (4a dama y música de Agustín Manuel) en la de Huertas ${ }^{21}$.

Orgullosos de su oficio, los actores de mayor nivel (que llegaron a formar auténticas dinastías) constituían, pues, un grupo «intelectual»-en tanto que dedicado al cultivo de «las letras»- con notoria influencia social que formaba parte de una nueva clase social intermedia e ilustrada. Y, dado que «...el demostrar conocimientos artísticos se acabó convirtiendo en la España del siglo XVII en una auténtica necesidad social entre las clases altas y medias intelectuales, o con pretensiones de serlo.... ${ }^{22}$, la posesión de cuadros fue su consecuencia natural.

El número de obras acumuladas por los actores no suele ser muy elevado pues habitualmente no sobrepasan la docena ${ }^{23}$. Hay, sin embargo, casos como

20. Ver María Asunción Flórez Asensio, «El Coliseo del Buen Retiro en el siglo XVII: teatro público y cortesano", Anales de Historia del Arte, no 8, 1998, pp. 171-195.

21. Orden de embargo de la Junta del Corpus. 13 de marzo de 1694. Archivo Municipal de la Villa, Madrid (AMV). Secretaría: 2-200-4.

22. Moran Turina, op. cit., p. 95. Como señala el autor, esta nueva actitud hacia la pintura se ve de forma palmaria entre los poetas, a muchos de los cuales fue requerido su parecer en el pleito sostenido por los pintores de Madrid en 1633. No debemos olvidar, sin embargo, que el aprecio por la pintura se centró inicialmente en la italiana y flamenca por lo que los pintores españoles, salvo excepciones, no contaron con el mismo reconocimiento por parte de sus contemporáneos, lo que no sucedía con literatos y prestigiosos comediantes. Ver Antonio Sánchez Jiménez, El pincel y el Fénix: pintura y literatura en la obra de Lope de Vega Carpio, Madrid, Universidad de Navarra-Iberoamericana-Vervuert, 2011, pp. 22 y 34. Ver también del mismo autor «Paralelos entre pintura y poesía durante el Siglo de Oro español: las poses de El Greco y Lope de Vega en la transición de artesanos a artistas», en M. Tietz y M. Trambaiolli (eds.), El autor en el Siglo de Oro. Su estatus intelectual y social, Vigo, Editorial Academia del Hispanismo, 2011, pp. 379-395, 383-384 y 387.

23. «Seis cuadros grandes de diferentes hechuras y marcos negros» figuran entre los bienes embargados en 1674 a Félix Pascual y Ana de Andrade, que incluyen, además, «... un escritorio de ébano y marfil $=$ dos espejos de armar $=$ dos escaparates vacíos $=$ un brasero de nogal bronceado $=$ seis almohadas de brocatillo $=$ cuatro sillas de nogal y las cubiertas del geno [ilegible] las almohadas $=[\ldots]=$ una alfombra de seis varas de diferentes colores... ». AMV. Secretaría: 2-197-19. 
los de Luisa Fernández, a la que por orden de la Junta del Corpus se embargan en 1673 veintinueve pinturas entre "chicas y grandes»" ${ }^{24}$, y el de su colega Juan Álvarez al que en 1713 se le embargan ${ }^{25}$ veintidós pinturas religiosas, además de "Una lamina en cristal de nra. Sra. de media vara de alto con marco imitado a concha», «Tres laminas de a tercia de difer[ente]s tamańos» $\mathrm{y}$ «Dos sobreventanas apaisadas con tarjetas doradas». La mayoría de estas obras representaban a diversos santos como San Francisco de Asís, San Francisco Javier, San Francisco de Paula y San Pedro de Alcántara, cada una de las cuales media «tres cuartas de alto con marco negro" y otras "dos, la una de S[a]n Anto[nio] y la otra de $S[a] n$ Juan de Dios de dos tercias de alto con marcos negros y perfil dorado». Algo mayores eran "Otras dos pinturas, la una de $S[a] n$ Jerónimo y la otra del Ángel de la Guarda de vara y media de largo y vna de ancho con marcos negros y perfiles dorados» $\mathrm{y}$ "Otra pintura de $S[$ an] ta Theresa de vara y media de alto y una de ancho con marco negro». Por último, «Una pintura de la negac[i] on de $S[a] n$ Pedro de dos varas y media de ancho y vara y media de alto con marco negro y perfil y tarjetas doradas». Seis, también de diferentes tamaños, eran representaciones de Vírgenes y Cristos: «Una nra. Sra. de la Humildad de media vara de alto con marco negro", "Otras dos pinturas, la una de nra. Sra. del Carmen y la otra de Jesús Nazareno de tres cuartas de alto con marco negro", "Otra de nro. S[eñ]or en el sepulcro de una vara en cuadro con marco negro", "Otra de un Sto. Ecce Homo de vara y media de largo con marco negro y perfiles dorados», "Otra de un Sto. Xpto. Crucificado de dos varas de largo y una y cuarta de ancho con marco negro». El actor poseía, además, "Otras dos pinturas la una de un niño de Pasión y un S[a]n Juan de tres cuartos de alto con marcos negros y tarjetas doradas", "Otra de la Huida a Egipto de dos varas de ancho", siendo posiblemente las más valiosas "Dos cabezas de S[a]n Pedro y S[a]n Pablo de tres cuartas de alto con marcos de lo mismo» y "Otra Pintura de nra. Sra. de la Contemplac[i]on de una tercia de alto con vidrio cristalino delante y marco tallado y dorado». Muy devoto de la virgen parece haber sido su colega Juan de Castro (segundo gracioso en la compañía de Garcés), según

24. AMV. Secretaría, 2-197-20. Ver la biografía de la actriz en María Asunción Flórez Asensio, «Fernández, Luisa», Diccionario Biográfico Español, Vol. XVIII, Madrid, Real Academia de la Historia, 2011, pp. 574-575, así como la entrada correspondiente en el Diccionario biográfico de actores del teatro clásico español (DICAT), T. Ferrer Valls (dir.), Kassel, Reichenberger, 2008.

25. Segundo galán de la compañía de José Garcés, ese año se dictó auto de prisión contra él por negarse a representar y se ordenó el embargo de sus bienes salvaguardando la dote de su mujer, Teresa Polop (que ascendían a 58.445 reales), gracias a que la actriz presentó un «... mandam[ien] to de amparo dado por el Sr. Dn. Diego Pellicer y Tovar del Consejo de su Magd. y su Alcalde de Casa y Corte, refrendado de Joseph Calvo de Velasco, [e]s[criba]no de Prov[inci] a... ". AMV. Secretaría: 2-201-16. Para los beneficios legales que obtenían las actrices por su condición de mujeres de cara a resguardar su hato y dote ver Carmen Sanz Ayán, "Éxito y crédito: funciones del hato de una actriz en la empresa teatral áurea», en F. Pedraza Jiménez, R. González Cañal y A. García González (eds.), Damas en el tablado. XXXI Jornadas de Teatro Clásico (Almagro, 1 a 3 de julio de 2008), Almagro, UCLM, 2009, pp. 53-82. 
se desprende del contenido de las nueve obras que se le embargaron ese mismo año ${ }^{26}$, cinco de las cuales eran imágenes Marianas.

$\mathrm{El}$ inventario de las pinturas en poder de ambos actores parece un reflejo de las que Peribáñez reserva para las paredes de su casa:

$\begin{array}{ll}\text { PERIBANEZ: } & {[\ldots] \text { sólo quiero }} \\ & \text { que haya imágenes pintadas: } \\ & \text { la Anunciación, la Asunción, } \\ & \text { San Francisco con sus llagas, } \\ & \text { San Pedro Mártir, San Blas } \\ & \text { contra el mal de la garganta, } \\ & \text { San Sebastián y San Roque, } \\ & \text { y otras pinturas sagradas; } \\ & \text { que, retratos, es tener } \\ & \text { en las paredes fantasmas. (vv. 1007-1016) }\end{array}$

Aunque la mayoría de los cuadros que poseían los comediantes parecen haber sido pinturas religiosas, fundamentalmente Vírgenes y Cristos, también encontramos en sus casas bastantes "países»" ${ }^{27}$, además de algunos floreros, bodegones ${ }^{28}$ e, incluso, retratos. Un buen ejemplo de esta variedad lo constituyen los cuadros embargados a varias actrices en diferentes años. Sólo dos de las dieciocho pinturas embargadas en 1665 a Mariana de Borja eran de tema religioso: «Una imagen de la Soledad con marco negro, de dos varas de largo, otra pintura de un Santo Cristo del mismo tamaño». Las restantes eran seis "países fruteros con marcos negros» y diez «pinturas diferentes con marcos negros de a vara de largo» ${ }^{29}$. De los nueve cuadros embargados en 1673 a María de los Santos, sólo uno era religioso («un cuadro de Santa Teresa»), siendo los otros «seis países con marcos negros» y dos "fruteros iguales con marcos»"

De estos datos se desprende que el carácter y aficiones de sus propietarios debían jugar un papel predominante en la elección de las obras. Muy devota de

26. «Una pintura de nra. Sra. de la leche de dos varas de largo y vara y media de ancho con marco tallado en blanco $=$ Otra de nra. Sra. de Belén de una vara de largo y tres cuartas de ancho con su marco negro y perfiles dorados = Otra de nra. Sra. del Pilar del mismo tamańo y marco que la anter[ior] = Otra de nra. Sra. de la Concepción de poco mas de vara de largo con su marco negro y perfiles tarjetas dorados = Otra de Sta. Teresa de dos varas de largo con su marco negro = Otra del Salvador de dos varas de largo sin marco = Otra del Xpto. De Burgos de vara de largo su marco en blanco = Otra de Jesús Nazareno del mismo tamańo y marco = Otra de la encarnac[i] on de vara de ancho y dos tercias de alto con marco blanco...». AMV. Secretaría: 2-201-16.

27. "cuatro países de vara y media de largo con marcos negros», además de dos cuadros religiosos (un «Nacim[ien] to de nro. S[eń]or» y un Santo Domingo, ambos de dos varas y media de largo con marcos negros) les fueron embargados en 1713 a Juan de Cárdenas y Paula María de Rojas (tercer galán y dama en la compañía de Garcés). AMV. Secretaría: 2-201-16.

28. "Dos fruteros de tres cuartas en cuadro con sus marcos negros» le embargaron al autor José de Prado en 1713. AMV. Secretaría: 2-201-16.

29. Emilio Cotarelo y Mori, Actores famosos del siglo XVII: Sebastián de Prado y su mujer Bernarda Ramírez, Madrid, Tip. Revista de Archivos, Biblioteca y Museos, 1911, p. 156. Citaré por Actores famosos... Prado.

30. AMV. Secretaría: 2-197-20. 
la Virgen y aficionada a las escenas de caza parece haber sido Luisa Romero ${ }^{31}$ ya que entre las "pinturas» tasadas en el recibo de dote (1666) figuran ocho «lienzos países de cazas», uno de los cuales representaba a un tigre y otro a un jabalí, tasados cada uno en 150 reales y los demás en 8 ducados cada uno. Los restantes cuadros son un «besugo» (33 reales), «dos fruteros» (60 reales), seis "países» tasados cada uno en dos ducados, "quince estampas de francia» (210 reales), siete "lienzos ordinarios» (84 reales), «un retrato de una nińa en pie vestida de monja» (88 reales). De los 11 cuadros religiosos que poseía la actriz siete eran Vírgenes de distintas advocaciones cuyos precios oscilan entre los 110 y los 250 reales, dos eran Nacimientos (uno en tabla y otro en lienzo «copia del Espańoleto» de «dos varas poco mas o menos» tasado en 40 ducados o 440 reales) y los otros dos un Descendimiento y un San Francisco. Luisa poseía, además, numerosos trajes y joyas entre las que se cita «...una caja de retrato con dos figuras pintadas de porcelana y otras dos por de dentro y un espejo por detrás y esmaltada por de dentro de turquesado... » tasada en 220 reales.

Muy interesantes son también algunos de los veintitrés cuadros embargados en 1686 a Eufrasia María de Reina, primera dama de la compañía de Rosendo López de Estrada. Entre ellos figuran los habituales floreros («seis floreros de tres cuartas de ancho con sus marcos dorados y negros, otros dos floreros de vara de alto con sus marcos dorados y negros») y, sobre todo, pinturas religiosas: «...un Santo Xpto. de burgos de dos varas y media de alto, con su marco dorado y negro con sus cortinas y cenefa de tafetán azul guarnecidas con encajes negros [...] otro cuadro de nuestra señora de los dolores, y otro de la de los desamparados del mismo tamaño de tres cuartos con sus marcos dorados y negros y cuatro cartelas cada una ...». Los restantes cuadros religiosos se salen de lo habitual ya que representan escenas: «... otro cuadro de la familia Santa de vara y cuarta de alto con su marco dorado y negro y sus cuatro cartelas [...] tres pinturas, una de la huida a Egipto y otra del nacimiento y otra de nuestra señora con el niño en los brazos y otras figuras y un juego de Ángeles de vara

31. Hija del autor Bartolomé Romero y de Antonia Manuela Catalán, célebres comediantes ambos como también lo fueron Luisa y su hermana Mariana, famosas, además, por su habilidad como músicas. En 1666 Luisa se casó con Carlos Vallejo, miembro de otra importante dinastía de actores. La actriz aportó al matrimonio una dote de 158.721 reales, de los que 3.195 correspondían al montante de las pinturas. Archivo Histórico de Protocolos (AHP). Po 10476, fo 827-828: Francisco Castellanos. Ver la biografía de la actriz en María Asunción Flórez Asensio, «Romero, Luisa», Diccionario Biográfico Español, Madrid, Real Academia de la Historia, vol. XLIV, 2013, pp. 340-342 y la entrada correspondiente en el DICAT. La situación familiar de Luisa parece haber sido bastante acomodada; de hecho, en 1637 Romero y Antonia Manuela ya eran dueńos de dos casas en el barrio del Mentidero: una en la calle Amor de Dios esquina con la de Santa María (parece que la adquirieron en 1626 por 2.300 ducados) y otra en la calle de Francos (hoy Cervantes) esquina con la del Niño por la que en 1659 el Conde de Pliego pagaba 2.400 reales de alquiler anual. Ver Hugo Albert Rennert, The Spanish Stage in the time of Lope de Vega, New York, The de Viune Press, 1909, p. 582; Cristóbal Pérez Pastor, «Nuevos datos acerca del histrionismo espańol de los siglos XVI y XVII» (2a serie), Bulletin Hispanique, no XVI, 1914, pp. 209-224 y 458-487, p. 221. 
y media de ancho con sus marcos negros» ${ }^{32}$. La actriz poseía, además, «dos retratos el uno de eufrasia y el otro de Damián de Castro de dos varas y media de alto y dos varas de ancho con sus marcos negros», que estaban situados en su alcoba, la parte mas privada de la casa. Lo más novedoso eran, sin embargo, seis cuadros de tema mitológico: «...cinco prespetivas de dos varas de ancho y vara y media de alto, todas de la fábula del robo de Elena, con sus marcos negros, otra pintura del mismo tamańo del juicio de los dioses con su marco negro».

Los países, floreros y bodegones eran géneros pictóricos claramente relacionados con el desarrollo de las clases urbanas acomodadas y figuran de forma habitual entre los cuadros en posesión de actores. El bodegón, que parece haber desarrollado en España unas características propias, era un género destinado al disfrute privado ya que satisfacía las necesidades de un público que se guiaba por su gusto y no por un sistema codificado de reglas ${ }^{33}$. Ese era también el público que asistía al teatro e impulsó la creación de la «comedia nueva», un género teatral alejado del academicismo y escrito, como resalta Lope $^{34}$ con ironía ante sus detractores, «...por el arte que inventaron / los que el vulgar aplauso pretendieron / porque como las paga el vulgo, es justo / hablarle en necio para darle gusto». Dada su doble condición de protagonistas de estas obras teatrales y miembros de esas clases urbanas acomodadas, el bodegón -y su variante el florero, tan de moda en la segunda mitad del siglo ${ }^{35}$ - era, pues, muy apropiado para los miembros de la profesión cómica.

Por lo que se refiere a los retratos, una «curiosidad usada en la Corte» ${ }^{36} \mathrm{y}$ clara señal de cierta posición social, aunque no es frecuente encontrarlos entre los cuadros que poseían los actores, tampoco es inusitado. Los documentos hacen referencia a varios de ellos que, curiosamente, en la mayoría de los casos son retratos de actrices. Un retrato de Bernarda Manuela, apodada la Grifona, poseía el músico Juan de Serqueira que había estado amancebado con la actriz. Tras la muerte de Bernarda «...la hizo retratar difunta y puso en un nicho la pintura con dos cortinas y de noche le encendía dos luces y rezaba el rosario delante del retrato...», lo que le costó ser encarcelado en 1691 por

32. Como prueba de su religiosidad tenemos los «ocho relicarios de a tercia de alto, de matices de seda con sus marcos dorados y negros», y los «dos escaparates de concha y ébano con sus corredorcillos bronceados y vidrieras cristalinas y en el uno una nuestra señora de la Concepción de talla con su corona de plata y peana dorada y en el otro un Sancto Cristo crucificado de marfil bronceada [sic] con floreros dentro en el uno y el otro». AMV. Secretaría: 2-199-4.

33. Javier Portús Pérez, «Significados sociales en el bodegón barroco español», en E. García Santo-Tomás (ed.), Materia crítica. Formas de ocio y de consumo en la cultura áurea, Madrid, Universidad de Navarra-Iberoamericana-Vervuert, 2009, pp. 169-189, p. 172; y William B. Jordan y Peter Cherry, Spanish Still Life from Velázquez to Goya, Londres, National Gallery Publications, 1995.

34. Lope de Vega, Arte nuevo de hacer comedias (1609). Edición de E. García Santo-Tomás, Madrid, Cátedra, 2006, p. 133.

35. Ver W.B. Jordan y P. Cherry, op. cit., pp. 129-145.

36. María de Zayas y Sotomayor, "El prevenido engañado», en sus Novelas amorosas y ejemplares (Zaragoza, 1637). Edición de Julián Olivares, Madrid, Cátedra, 2000, pp. 295-342, p. 319 . 
la Inquisición ${ }^{37}$. Debió quedar escarmentado porque entre los bienes que se le embargaron en 1713 por orden de la Junta del Corpus no aparece ningún cuadro profano pero sí pinturas religiosas y dos imágenes ${ }^{38}$. Un retrato de su mujer, la actriz Manuela Bustamante, además de «una pintura de mas de dos varas de indio» figuran entre los bienes embargados en 1664 a Félix Pascual ${ }^{39}$. Dos retratos de Antonio de Prado, uno «entero» y otro de medio cuerpo, tasados en 150 y 50 reales respectivamente ${ }^{40}$, figuran en la relación de bienes hecha por el actor en 1632 al casarse con Mariana Vaca Morales.

Lamentablemente, salvo el cuadro anónimo titulado Alegoría de la Vanidad, hoy en el Monasterio de las Descalzas Reales, en el que se representan las dos etapas vitales de una mujer que suele identificarse con la actriz María Calderón, el único ejemplo que nos ha llegado es el retrato de Juan Rana (Fig. 2 página siguiente) donado en 1871 a la Real Academia Española de la Lengua por D. Adolfo de Castro, que tampoco es propiamente un retrato ya que representa al personaje ${ }^{41}$ (Juan Rana) y no al actor (Cosme Pérez).

Muy diferente es el caso de las pinturas mitológicas, verdaderamente escasas pese a que los escritores de la época citan a varios pintores muy hábiles en representar «poesías» (es decir, fábulas mitológicas). Los dramaturgos las mencionan también como parte de la decoración de las casas acomodadas.

37. Genealogía, origen y noticias de los comediantes de España. Fuentes para la historia del teatro en España II. Norman D. Shergold y John E. Varey (eds.), Londres, Támesis, 1985, p. 198. Permaneció encarcelado hasta 1693, año en el que la Villa le dio 2.200 reales «...por haber salido de una prisión y estar sin vestidos ni cosa q[ue] ponerse y para desempeñarse de lo que había caudado en d[ic]ha prisión». AMV. Secretaría: 2-200-3.

38. AMV. Secretaría: 2-201-16. Ese año Serqueira era músico principal de la compañía dirigida por José de Prado. Según consta en el acta del embargo, éstas fueron una "pintura de yeso de nra. Sra. de la Cueva Sta. de dos tercias de alto con marco dorado» además de otros cinco cuadros de distintas advocaciones (San Francisco, Santa Catalina, un Nacimiento, un Santo Cristo de Burgos, Santa Verónica). Las dos imágenes eran «Un Niño Jesús de Nápoles con su peana dorada de tres cuartas de alto $=$ Un S[a]n Anto[nio] de Padua de Nápoles del mismo tamaño con su peana dorada».

39. Norman D. Shergold y John E. Varey, Los autos sacramentales en Madrid en la época de Calderón. Madrid, Edhigar, 1961, p. 175.

40. Piedad Bolaños Donoso, «Antonio de Prado y su esposa Mariana de Morales (1632)», Criticón, 2007, no 99, pp. 167-192, p. 180.

41. Según Bergman el retrato no fue encargado por el actor sino posiblemente por un personaje de la Corte. Para la investigadora su mera existencia fue un hecho tan excepcional que inspiró nada menos que tres entremeses en cuyo título se alude al retrato. Dos de ellos, uno de Solís y otro atribuido a Villaviciosa, tienen el mismo título: El retrato de Juan Rana; el tercero (El retrato vivo) es de Moreto. Ver Hanna E. Bergman, "Juan Rana se retrata», en Homenaje a Rodríguez Moñino, 2 vols., Madrid, Castalia, 1966, vol. I, pp. 65-73, pp. 70-71. Ver también Alicia Álvarez Selleres, «Iconografía del retrato de actor: "La Calderona”, "Juan Rana” y Pablo de Valladolid», en Alicia Álvarez Sellers, Del texto a la iconografia. Aproximación al documento teatral del siglo XVII, Valencia, PPU, 2008, pp. 277-320. Cosme Pérez fue el "gracioso» más celebre de todo el siglo XVII. Ver Flórez Asensio, "Diego Velázquez y Cosme Pérez... » y Francisco Sáez Raposo, Juan Rana y el teatro cómico breve del siglo XVII, Madrid, Fundación Universitaria Española, 2005. 
Fig. 1.

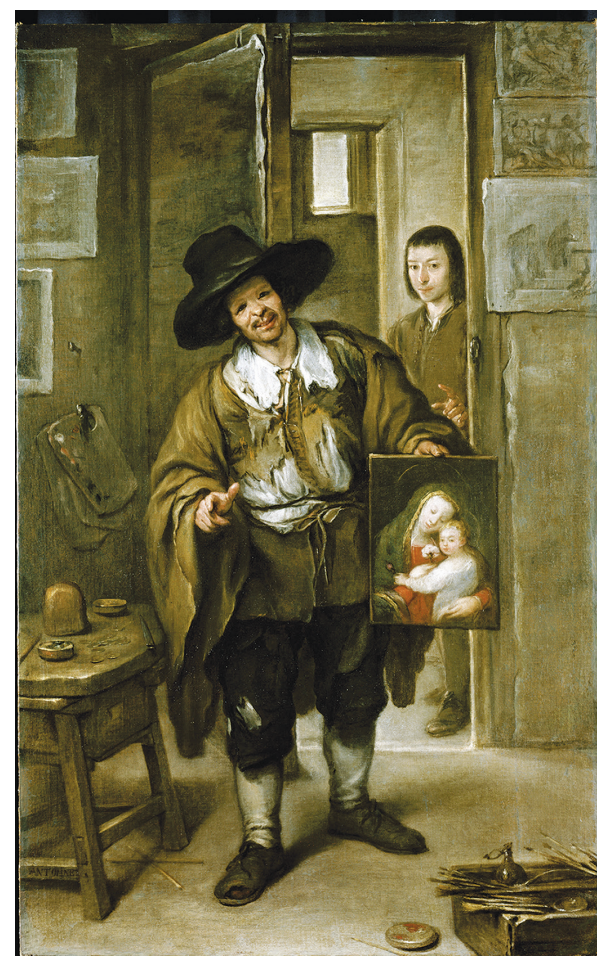

Fig. 1. - Antolinez José (1635-1675): «En el taller» $(202$ x $126 \mathrm{~cm})$. Munich, Alte Pinakothek, Inv. Nr. 8577.

bpk de (C) für Kunst de Bildagentur, und de Kultur Geschichte (ou lebpk d'abréviatio), Berlin/Gemälde Reproduktion.

Fig. 2.

Fig. 2. - Anónimo, «Juan Rana»

(88 x 49 cm). Madrid, Real Academia Española [24].

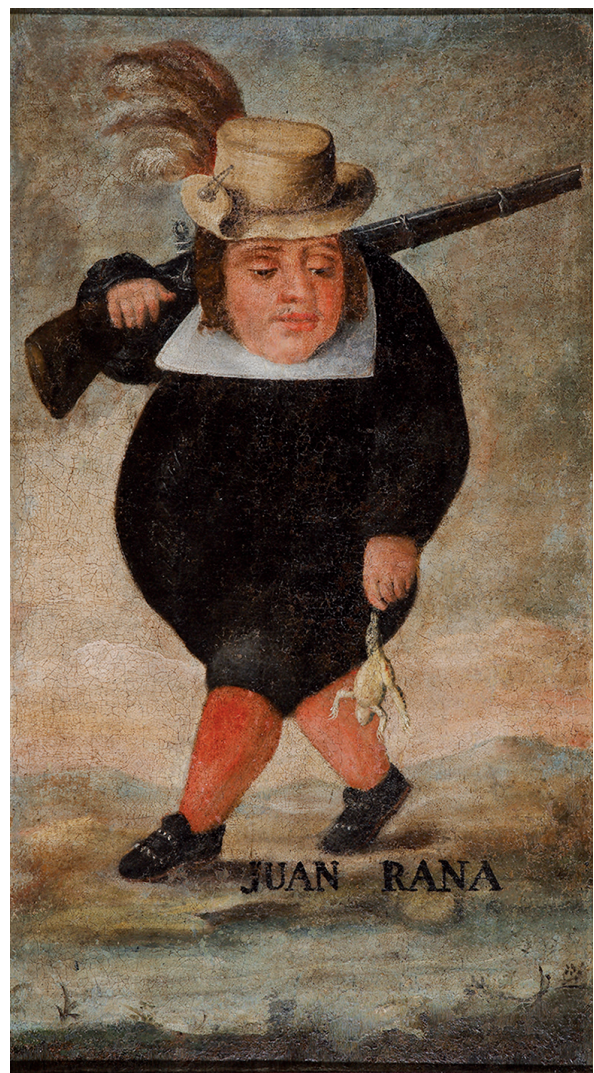


Varias de ellas, todas de «buena mano» decoran la casa de Feliciano, el protagonista de La prueba de los amigos de Lope (p. 130):

$\begin{array}{ll}\text { FULGENCIO: } & {[\ldots]} \\ & \text { Esta es su casa; entrad. } \\ \text { RICARDO: } & \text { ¡Qué sala hermosa! } \\ \text { FULGENCIO: } & \text { La casa es buena, y la pintura alabo. } \\ \text { RICARDO: } & \text { Esta Lucrecia es singular. } \\ \text { FULGENCIO: } & \text { Famosa. } \\ \text { RICARDO: } & \text { ¡Bueno, tras la cortina, está el esclavo! } \\ \text { FULGENCIO: } & \text { De Urbina es la invención. } \\ \text { RICARDO: } & \text { ¡Era excelente! } \\ & \text { ¡Bueno es aquel Adonis que está enfrente! } \\ & \text { ¡Lindas telas son éstas!. }\end{array}$

Con pinturas mitológicas «que persuaden al desdén» adorna sus aposentos Diana, la protagonista de El desdén con el desdén de Moreto, que desprecia a los hombres:

CARLOS:
$[\ldots]$
A su cuarto hace la selva
de Diana, y son las ninfas
sus damas, y en este estudio
las emplea todo el día.
Sólo adornan sus paredes
de las ninfas fugitivas
pinturas que persuaden
al desdén. Allí se mira
a Dafne huyendo de Apolo;
Anaxarte, convertida
en piedra por no querer;
Aretusa, en fuentecilla,
que al tierno llanto de Alfeo
paga en lágrimas esquivas. ${ }^{42}$

Dado que las dos obras arriba citadas se escribieron para los corrales de comedias, resulta evidente que los temas mitológicos eran conocidos por la gran mayoría del público que asistía a ellos ${ }^{43}$, además de protagonizar las fiestas teatrales cortesanas representadas principalmente en el Coliseo del Buen Retiro, de gran éxito también entre el público común que tenía acceso igualmente a

42. Agustín Moreto, El desdén con el desdén. Edición de Francisco Rico, Madrid, Castalia, 1978, pp. 72-73. Las pinturas también caracterizan a la virtuosa Isabel de Virtud, pobreza y mujer de Lope, que decora su casa con cuadros religiosos rechazando las «vanas fábulas del Mudo, de Bassan ni de Tiziano». Ver en Portús Pérez, Pintura y pensamiento..., p. 175.

43. Un buen ejemplo lo constituyen los versos que le dedica a Isabela el Vejete que pretende desposarla en el Entremés de la boda, y los violines de Francisco de Castro, gracioso y «representante de una de las Compañías de la Corte»: «VEJETE: .../Y tu Diana bella,/mira este llanto, escucha mi querella;/daréte el blanco toro,/de quien Europa enamorada goza,/de Midas el tesoro,/y de Febo tu hermano la carroza,/el vellocino hermoso,/que de Jasón fue premio venturoso,/y por bella, y lozana,/juzgaré que mereces la manzana». Francisco de Castro, Primera parte de Alegría Cómica, Zaragoza, 1702, fo 46-55, fo 54. 
este teatro. Sirva de ejemplo lo sucedido en 1652 con La fiera, el rayo y la piedra de Calderón de la Barca, que dramatiza la fábula de Anaxarte. Tras ser vista por los reyes el primer día, por los consejeros el segundo y el tercero por el Ayuntamiento madrileño, se representó a «... todos con tan grandes gastos, y frecuencia de pueblo y señores, que es indecible, duro el verla 40 días, y cuando durara mas fuera lo mismo, porque se despoblaba el Reino por venir a verla ${ }^{44}$.

Las «cinco prespetivas [...] todas de la fábula del robo de Elena» y el «juicio de los dioses» de Eufrasia María constituyen, pues, uno de los pocos casos documentados de pintura mitológica en poder de particulares dado que su proliferación y difusión fue muy limitada debido a que la presencia del desnudo, consustancial con las fábulas clásicas, las incluía dentro del grupo de obras calificadas en la época de "deshonestas», por lo que su posesión podía traer graves complicaciones a sus dueños. Sólo aquellos que se encontraban por encima de las leyes comunes -el rey y la alta nobleza- podían permitírselas, hasta el punto de que, como señala Gállego, la pintura mitológica será durante el siglo XVII «monopolio de los reyes y algunos grandes señores», mientras que otros segmentos de la población, cuya acomodada situación económica les permitiría acceder a este tipo de obras, «... no se atreven a imitar a los príncipes en su afición a lo clásico, por miedo de parecer malos cristianos...» ${ }^{45}$ dada la evidente sensualidad de estas obras. Esta característica es, precisamente, la que aprovecha Lope de Vega en La viuda valenciana para "pintar» la doble moral de Leonarda, su protagonista, quien, al ser abordada por un fingido vendedor de estampas (en realidad uno de sus pretendientes con poco éxito), que le ofrece obras de pintores famosos (un Adonis de Tiziano y otras de Rafael, Cornelio Cort, Martin de Vos y Federico Zuccaro) pregunta hipócritamente si no trae

44. Escrivense los sucesos de la Europa y otras partes desde el abril de 1652 hasta el Marzo de 1653. BN. Mss 2.384, fo 42. En la obra se utiliza una escena basada en la técnica del cuadro dentro del cuadro: la gruta de las Parcas que, según la acotación de la edición de la obra de 1664, deben aparecer «como las pintan». Egido («Introducción», p. 40) cree que Calderón o el escenógrafo de la obra (Baccio del Bianco) pensaban en Las Hilanderas de Velázquez ya que el tema no es muy habitual en la pintura española. El cuadro de Velázquez suele datarse en torno a los años centrales de la década de 1650. Ver Jonathan Brown, Velázquez. Pintor y cortesano, Madrid, Alianza, 1986, p. 252.

45. J. Gállego, Visión y simbolos..., pp. 53 y 69. Según López Torrijos la pintura mitológica «... abunda en aquellas colecciones cuyos propietarios están mas cerca del rey [Felipe IV] (y por tanto, de su influencia, bien real, bien por halago a su persona) y, sobre todo, en las de aquellos que han estado en misiones extranjeras -Flandes e Italia principalmente- y que por cuestiones de adaptación del gusto o de prestigio, ven la mitología como tema habitual, traen numerosas obras extranjeras del género a su regreso a España y, en algún caso, lo fomentan también entre los pintores de nuestro país». Hay que tener en cuenta también que la Iglesia, que era el comprador mas importante de pinturas en la España del XVII, «...no encargaba mitología ni a título institucional, ni a título privado...» debido precisamente al rigor moral de sus miembros, mayor que el que existía en otros países como Italia, donde el clero no desdeñaban la posesión de este tipo de pinturas. Ver Rosa López Torrijos, La mitología en la pintura española del Siglo de Oro. Madrid, Cátedra, 1995, p. 17. 
«cosas de Dios» (vv. 890-904) precisamente cuando ha decidido "gozar» a Camilo en secreto y sin casarse con él ${ }^{46}$.

Su concepción pecaminosa «...explica, pues, la practica ausencia del desnudo en la pintura española del Barroco, ya que comprometía, primero, a la parte mas débil: el pintor y el cliente de tipo medio ${ }^{47}$. Creo, por ello, que el hecho de que una actriz, y además muy famosa, poseyera cuadros de este tipo ańade aún mas valor al hecho: su mera posesión revela el carácter de Eufrasia María, su escaso temor a las diatribas con las que los moralistas fustigaban a la profesión cómica (especialmente a las actrices) y el orgullo con el que desempeñaba su oficio. Tan importante como su posesión me parece la situación de las pinturas en la casa de la actriz pues, según se desprende del embargo, no parece que estuviesen en su alcoba o en otras estancias reservadas de la casa, sino en la «sala». Ello se explicaría porque, posiblemente, no había en ellas ningún «deshonesto» desnudo ${ }^{48}$ ya que, aunque el tema del robo de Elena-uno de los mas populares en la época- ${ }^{49}$ se presta a cierta libertad en la representación indumentaria de la protagonista, los ejemplos conservados de Juan de la Corte, del que se conocen actualmente cinco cuadros con este tema ${ }^{50}$, nos permiten observar que la representación de los cuerpos se mantiene dentro de las normas del recato exigido por la más estricta moral. Lo mismo sucedería con el «juicio de los dioses», un tema poco habitual en la pintura española de la época.

Juan de la Corte, el pintor flamenco arriba citado afincado en Espańa desde, al menos, 1613 y muerto en Madrid en 1660, era «...muy buen pintor de países, batallas, y perspectivas, como lo demuestran sus muchas obras, que están repartidas por diferentes casas, y palacios dentro, y fuera de esta Corte; y especialmente en el Retiro en el Saloncete. Fue pintor del Rey aunque no el de más lucida habilidad; pero en lo que mas se aventajó, fue en historiejas pequeñas, ya de fábulas, o ya de la Sagrada Escritura, con algún trozo de perspectiva, o país $\rangle^{51}$. Pese a las reservas de Palomino, parece que gozó de bastante prestigio.

46. Lope de Vega, La viuda valenciana, Teresa Ferrer Valls (ed.), Madrid. Castalia, 2001, pp. 166-169. Ver también Frederick A. de Armas, «De Tiziano a Rafael: pinturas y libros en $L a$ Viuda Valenciana de Lope», en I. Lerner, R. Nival y A. Alonso (eds.), Actas del XIV Congreso de la Asociación Internacional de Hispanistas, New York, 16-21 de Julio de 2001, 2 vols., NewarkDelaware, Juan de la Cuesta, 2004, vol. II, pp. 165-172.

47. López Torrijos, op. cit., p. 22.

48. En 1641, al otorgar testamento, D. Rodrigo de Herrera ordena que algunos cuadros de su rica colección de pinturas «... que por ser deshonestos no estaban colgados, y no quería se vendiesen en España sino en Italia. Era habitual que estos cuadros con representación de desnudos, además de situarse en salas reservadas de la casa, se ocultasen bajo cortinillas. Ver en López Torrijos, op. cit., pp. 20-21.

49. Sobre la popularidad del ciclo troyano y su representación plástica en el siglo XVII, que aparece también en las pinturas enviadas a América, ver López Torrijos, op. cit., pp. 198-230.

50. Uno se conserva en la finca El Retiro, en Churriana; otros dos, procedente del Buen Retiro, se encuentran hoy en el Museo del Prado. Existe otro en una colección particular madrileña. Del quinto, desaparecido durante la Guerra Civil, se conserva una fotografía. Ver López Torrijos, op. cit., pp. 206, 209 y 212-13.

51. Palomino, «El Parnaso Español... », p. 153. 
Las dos obras con el tema del rapto de Elena, una de «dos varas y tercia de largo y siete cuartas de alto» y otra una «Sobreventana» de vara y media de largo por media vara de alto que decoraban el palacio del Buen Retiro fueron tasadas en 720 y 360 reales respectivamente en el Inventario de 1701-1703 (Inventarios reales II: 315 y 318. No 484 y 514). Nada menos que 19 pinturas de su mano figuran entre los bienes de $\mathrm{D}^{a}$ María de Vera, viuda de D. Juan González de Uzqueta, quien poseía en 1692 más de 750 cuadros valorados en 148.805 reales, entre ellos obras de Tiziano, Tintoretto, Veronés, Teniers, Velázquez y Sánchez Coello. Dos de los retratos atribuidos a Sánchez Coello ( un caballero de Calatrava» y una mujer) se tasaron en 620 reales mientras que el «retrato de Felipe IV con su bastón» y «un retrato de un mozo con garnacha y un ramo de azar en las manos» de Velázquez se tasaron en 1.550 y 240 reales respectivamente. Por lo que se refiere a las obras atribuidas a Juan de la Corte, tres pinturas «tocantes a la historia de Troya» se tasaron en 3.300 reales $^{52}$.

Estos precios nos permiten afirmar que no era sólo Juan de la Corte un artista al que podían recurrir los miembros acomodados de la profesión cómica, ya que éstos podían permitirse también comprar cuadros de Velázquez. Como primera dama, y gracias fundamentalmente a su participación en fiestas palaciegas y autos del Corpus (por los que podía obtener fácilmente más de 3.000 reales $^{53}$ ), Eufrasia María tenía unos ingresos considerables. Así lo confirma también su faceta de autora, pues en la época se requería gran "caudal» para serlo ${ }^{54}$. Por tanto, aunque es muy posible que la mayoría de las pinturas que poseían los actores se debieran a artistas de no muy «lucida habilidad», no podemos descartar que entre ellas se encontrase alguna más valiosa, como el «...cuadro de una cabeza de Velázquez, que viene a ser un retrato del Marqués del Carpio...» que poseía Sebastián de Prado, según declara él mismo en el testamento que hizo al entrar en religión en $1674^{55}$.

52. Janine Fayard, Los miembros del Consejo de Castilla (1621-1746), Madrid, Siglo XXI, 1982, pp. 424, 427 y 429.

53. En 1675 Francisca Bezón y Fabiana Laura, primeras damas respectivamente de las compañías de Escamilla y Vallejo, cobraron 3.000 reales cada una por su participación en los autos del Corpus. Sin embargo, esta cantidad fue superada por Bernarda Manuela y Sebastiana Fernández, $3^{\mathrm{a}}$ y $4^{\mathrm{a}}$ damas de Vallejo, célebres ambas por sus habilidades musicales, que cobraron 3.366 reales cada una. AMV. Secretaría: 2-197-18. Los autos representados ese año fueron $E l$ Nuevo Hospicio de Pobres y El Jardín de Falerina. Ver los ingresos medios anuales de un actor de prestigio como Come Pérez en Flórez Asensio, «Diego Velázquez y Cosme Pérez...», pp. 235-236.

54. Por ser pobre y «...ser grande el caudal que es menester para autor...» renunció Jerónimo García a la autoría en 1681. Ver en Shergold y Varey, Los autos sacramentales en Madrid..., p. 351. En 1685 Eufrasia Maria y su colega Simón Aguado solicitaron al rey que, «...para poder mantenerse y satisfacer a los compañeros...", se les pagase una parte -al menos- de lo que se les debía (3.900 reales a Eufrasia y 5.400 reales a Simón) de las representaciones «particulares» hechas en palacio. En 1689 la deuda ascendía ya a 23.436 reales «que se están debiendo de atrasado" a seis compañías, entre ellas las de Eufrasia María y Simón Aguado. Ver Fuentes para la historia del teatro en España I. Representaciones palaciegas: 1603-1699. Estudio y documentos, Norman D. Shergold y John E. Varey (eds.), Londres, Támesis, 1982, pp. 1982: 166 y 198. Citaré por Fuentes $I$.

55. Cotarelo y Mori, Actores famosos ... Prado, pp. 171-172. 
Dado que, como ya vimos, en la época existía un floreciente comercio de pinturas en tiendas abiertas al público común, no es imposible que los floreros y países fuesen obra de pintores tan apreciados como Juan de Arellano, quien «...estudiando las flores por el natural, las llegó a hacer tan superiormente, que ninguno de los españoles le excedió en la eminencia de esta habilidad, de que hay varios testimonios en los templos, y casas de señores, y aficionados... ". Arellano tenía frente a las gradas de San Felipe «...obrador público de pintura cerca de cuarenta años, y fue una de las mas célebres tiendas de pinturas que hubo en esta Corte» ${ }^{56}$. Otro artista asequible era Lorenzo de Soto, quien «... se dedicó a los países, en que fue, sin duda, excelente». Tras abandonar la pintura profesional por un oficio burocrático, volvió a ella aunque «... ya por la edad, que seria mas de cincuenta años, ya por la falta de práctica [...] y de haberse adormecido su crédito en tan larga ausencia, y mudanza de empleo, fue menester ponerlos en público a vender en Palacio, y en la Puerta de Guadalajara»" ${ }^{57}$. Pintor de "...historiejas de la Vida de Cristo, y de la Virgen; y también de la historia de Abraham, Isaac, y Jacob en paisitos de muy buen gusto...», además de «retraticos pequeńos» que hacía con excelencia, todos los cuales «...ponía a vender en Palacio y otros sitios públicos, y los despachaba muy bien, porque parecían excelentemente...» fue don Francisco de Ochoa y Antolinez ${ }^{58}$, hermano de José de Antolinez.

Había, además, una serie de pintores bien conocidos por los actores dado que compatibilizaban su trabajo en los decorados de los festejos palaciegos (tan despreciado por Antolinez pese a ser discípulo de Rizi) ${ }^{59}$ con la pintura de bodegones y "países». Es el caso de Lorenzo Montero, considerado por Palomino ${ }^{60}$ muy buen pintor de "frutas, flores y países» además de acreditarse en la ejecución de «...las mutaciones de las comedias que se hacían en el Coliseo del Buen Retiro, a que asistió siempre, por lo bien, que se desempeñaba en todo; y especialmente en mutaciones de arboleda, jardín, u otras, donde hubiese algunos festones de flores, jarrones o guirnaldas, era una maravilla». Un caso semejante parece haber sido el de dos pintores ad honorem del rey: José de Ciezar, que «...sobresalió con especialidad en los países, y en las flores, que las hacía con superior excelencia...», además de pintar «muchas cosas al óleo», quien mostró una «...excelente habilidad en las mutaciones del coliseo del Buen Retiro». El otro, Bartolomé Pérez, yerno de Arellano, «llegó a hacer las flores

56. Palomino, «El Parnaso Español... », pp. 225-226.

57. Ibid., pp. 301-302.

58. Ibid., p. 339.

59. Principal responsable de las mutaciones del Coliseo del Buen Retiro durante varios ańos, Rizi quiso escarmentar a su discípulo obligándole a pintar un lienzo al temple para el teatro: «... estuvo todo el día Antolinez haciendo y deshaciendo, sin entrar, ni salir; al cabo de lo cual le dijo Rizi: ¿Ve aqui vuesa merced lo que es pintar paramentos? Anda muchacho (le dijo a un muchacho) y lava ese lienzo en aquel pilón; y así se ejecuto, quedando corrido nuestro Antolinez; corregida y castigada su vanidad.». Palomino, «El Parnaso Español... », p. 244.

60. Ibid., p. 379. 
tan bien como su suegro» ${ }^{61} \mathrm{y}$ "Asistió también mucho tiempo a las funciones del Coliseo, y casi siempre que se pintaba cortina, lo hacia él, porque tenia especial gracia, y primor para ello».

El hecho de que las tasaciones y embargos no indiquen el nombre de los pintores no excluye que éstos fuesen profesionales de reconocido prestigio; es más, cuando Claudio Coello tasa las pinturas de Calderón, pese a valorar «un cuadro de la Cena, con marco dorado, que esta en el oratorio» en 3.000 reales y en 3.300 «otro de San Francisco en éxtasis, pintura de Italia» ${ }^{62}$, no cree necesario indicar los autores de pinturas tan caras y mucho menos los de los restantes cuadros que poseía el dramaturgo, cuya colección estaba formada por 119 "pinturas y láminas», y en la que, si bien predominaban los cuadros religiosos, también había «ramilleteros» y "países». Aunque podemos considerarla excepcional por el número de obras, no lo es tanto si atendemos a los precios y temas ${ }^{63}$ de las mismas: 78 eran de tema religioso y el resto lo constituyen 22 «ramilleteros», 12 «cuadros de flores», 4 «paisillos» y 3 «países», oscilando el valor de cada uno entre 1 y 4 ducados $^{64}$. Éstos son también los cuadros que con frecuencia se mencionan en posesión de actores. Por otra parte, si tenemos en cuenta que entre las pinturas de la colección real tasados a la muerte de Carlos II se encuentran países y floreros a un precio tan asequible como los 360 reales en que se valoraron cada uno de los seis floreros pintados por Francisco Pérez Sierra $^{65}$ no podemos excluir la posibilidad de que los actores y actrices de mayor nivel económico y cultural recurriesen a profesionales bien cualificados.

No faltaban, por tanto, en Madrid pintores de calidad a los que un comediante de recursos podía recurrir. Una actriz de la categoría de Eufrasia María, dueña -como ya vimos- de «casas propias» en la calle Atocha ${ }^{66}$, podía

61. Ver en Palomino, «El Parnaso Español... », pp. 328 (Ciezar) y 315 (Pérez). Magníficos ejemplos del arte de ambos podemos ver en Jordan y Cherry, op. cit., pp. 135 y 139. Cat. núms. 50 (Arellano) y 52 (Pérez).

62. Cristóbal Pérez Pastor, Documentos para la biografía de D. Pedro Calderón de la Barca, Madrid, Real Academia de la Historia, 1905, p. 426.

63. Lope, sin embargo, parece haber tenido afición por las alegorías y los emblemas aunque no falten en su colección los retratos y cuadros religiosos como «una imagen en tabla de nuestra señora de la Concepción obra excelente de Carvajal» que deja en su testamento de 1627 a su amigo, el célebre predicador Fray Hortensio Félix Paravicino. Ver Portús Pérez, Pintura y pensamiento..., pp. 158-159 y Sánchez Jiménez, El pincel y el Fénix..., pp. 89-90. Luis de Carvajal fue uno de los pintores contratados por Felipe II para decorar El Escorial, donde realizó «una Estación en el claustro» y "otras pinturas al óleo para algunos altares de aquel gran templo». Palomino, «El Parnaso Español...», p. 65.

64. Pérez Pastor, Documentos para la biografía..., pp. 425-427.

65. Ver Inventarios Reales, II, p. 313. Núms. 457 a 462. Además de buen pintor al fresco y al temple, Pérez Sierra «... se aplicó a pintar algunos bodegoncillos, con diferentes baratijas, hechas por el natural, y algunas legumbres, y hortalizas, colocadas todas estas cosas con tanta arte, y buen gusto, que era un milagro». Palomino, «El Parnaso Español...», p. 376. En apenas 1.500 reales se tasaron cada uno de los cuadros de la serie sobre los trabajos de Hércules de Zurbarán (cuyo nombre omite el tasador) que adornaban el Salón de Reinos del Buen Retiro. Inventarios Reales, II, pp. 297-298.

66. AMV, Secretaría, 2-200-4. La posesión de casas era señal cierta de una vida acomodada 
permitirse contratar al ya citado Juan de Alfaro, discípulo de Velázquez, buen copista, paisajista y excelente retratista especializado en «...retratos pequeńos, que entonces se practicaban mucho y se pagaban mejor». Su contacto con el mundo literario y teatral de la época, además de su calidad artística están probados por el hecho de que el coleccionista D. Pedro de Arce, hijo del tratante de arte del mismo nombre y propietario de Las hilanderas de Velázquez ${ }^{67}$, le encargase la serie de "....retratos de medio cuerpo, de hombres eminentes, y poetas insignes para su museo» ${ }^{68}$. Pintor de "flores» era Gabriel de la Corte, quien «... copiando algunas del natural, y otras de Arellano y Mario [Nuzzi], y así llego a hacerlas prácticamente con gentil bizarría, y manejo, de que hay muchos juegos en diferentes casas, así de cestillas, y jarrones de flores, como de tarjetas, y guirnaldas con historieja [...] pero como no sabia hacer otra cosa, vivió siempre con gran miseria, ya pintando en las tiendas, ya haciendo juegos de floreros de diferentes tamaños, y poniéndolos en público a vender, donde la fuerza de la necesidad hacia darlos por muy bajo precio ${ }^{69}$. Pese a la negativa opinión que le merece a Palomino, en 1772 se inventarió un cuadro suyo, precisamente un Robo de Elena, en el palacio del Buen Retiro ${ }^{70}$.

Podemos hacernos una idea del adorno pictórico de la «sala» de la actriz gracias a la descripción que Castillo Solórzano hace de una casa madrileña acomodada en su comedia El Mayorazgo figura:

\begin{tabular}{|c|c|}
\hline INÉS: & Hermosa sala. \\
\hline Da ELENA: & ¿No celebráis las pinturas? \\
\hline URBINA: & $\begin{array}{l}\text { En esta amenaza a Adonis } \\
\text { el cerdoso jabalí } \\
\text { por dejarle a buenas noches; } \\
\text { aquí Europa surca el mar, } \\
\text { combatida de temores } \\
\text { en la taurífera piel } \\
\text { en que se disfraza Jove. }\end{array}$ \\
\hline Da ELENA: & Historias entendéis Urbina. \\
\hline URBINA: & Desto de transformaciones \\
\hline
\end{tabular}

pues aunque por su aspecto exterior las casas madrileñas «no parecen gran cosa» a los ojos de extranjeros como Francois Bertaut, ellos mismos nos informan de que eran «extraordinariamente caras» pese a no estar construidas «...mas que con ladrillo y barro, a causa de que hay poca cal, y que la piedra se tiene que sacar de siete leguas de lejos [...] Una casa que no pasaría sino por mediana en otra parte, se vende aquí por veinte y veinticinco mil escudos. Cuando un hombre construye, suponen que tiene mucho dinero en la bolsa...» (Antoine de Brunel). Cito a ambos por José García Mercadal, Viajes de extranjeros por España y Portugal. Desde los tiempos más remotos hasta comienzos del siglo XX, Valladolid, Junta de Castilla y León, 1999, Vol. III, pp. 408 (Bertaut) y 261 (Brunel).

67. Ma Luisa Caturla, «El coleccionista madrileño Don Pedro de Arce, que poseyó Las hilanderas de Velázquez», Archivo Español de Arte, 1948, no XXI, pp. 292-304; Fernando Marías, "Don Pedro de Arce ¿coleccionista o regatón? y Las hilanderas de Velázquez», Archivo Español de Arte, 2003, no LXXVI, pp. 418-425.

68. Palomino, «El Parnaso Espańol...», pp. 262-263.

69. Ibid., p. 326.

70. López Torrijos, op. cit., p. 217. 


$\begin{array}{ll}\text { Da ELENA: } & \text { sé mucho. } \\ & \text { Este camarín responde } \\ & \text { a esta sala; en él se ven } \\ & \text { países, medallas, flores, } \\ & \text { y algunos buenos retratos } \\ & \text { de los pinceles mejores } \\ & \text { desta corte }{ }^{71} .\end{array}$

Una acumulación semejante podría verse en casa de Eufrasia María cuya sala, además de con cuadros, se adornaba con tres escritorios (uno pequeño de concha y marfil de tres gavetas con un bufetico de nogal que le servía de pie y dos escritorios de ébano y marfil de ocho gavetas «y su alacena en medio cada uno y sus pies de nogal»), cuatro escaparates «de concha y ébano», uno de los cuales estaba «lleno de barros y búcaros y jícaras»; seis sillas de baqueta colorada nueva, cuatro taburetes pequeños y otros cuatro altos todos de baqueta. En la alcoba, además de los retratos de la actriz y de su marido, se encontraban «...cuatro tapices viejos que están colgados en la alcoba, un dosel de damasco encarnado [...] un bufete grande de nogal, un brasero de ébano embutido en bronce con su bacía de azófar, otro brasero de azófar...» y «una cama entera de dos cabeceras de palo santo de hechura salomónica» con cinco colchones «poblados de lana», sabanas, almohadas y colcha ${ }^{72}$.

Un actor o actriz de renombre gozaba, pues, de un entorno doméstico bien acondicionado y en ocasiones lujoso, con «tantos damascos, escritorios y cuadros» que -según expresión de María de Zayas ${ }^{73}$ - hacían que su casa pareciese «más de señora de título que de particular».

Parece, por tanto, que a partir de la segunda mitad del siglo XVII los autores y actores, muy alejados ya de los humildes oficios ejercidos inicialmente por sus primeros colegas, se habían integrado plenamente en la sociedad de la época, y muy especialmente en la madrileña. Haciendo cierto el pronóstico de Lope:
Un solador se ha vuelto caballero porque mudó de oficio con cordura, y subió por los grados de ventura, y halló la suya en ser farandulero ${ }^{74}$.

71. Cito por López Torrijos, op. cit., p. 86. Los subrayados en cursiva son míos.

72. AMV. Secretaría: 2-199-4. Un ajuar similar poseía en 1673 la actriz y música María de los Santos, a la que ese año se le embargaron por orden de la Junta del Corpus un brasero con su bacía, dos espejos cuadrados con marcos dorados, ocho almohadas de terciopelo carmesí, una cama de granadillo con colgaduras y cuatro colchones, sábanas, almohada y frazada, un bufetillo de estrado de carey, un «escritorillo» de la India, una escribanía de ébano y marfil, dos escritorios de concha con sus bufetes de nogal, cuatro cortinas y, además, los nueve cuadros ya citados. AMV. Secretaría: 2-197-20.

73. «El castigo de la miseria», en Novelas amorosas y ejemplares..., p. 257.

74. Tomo la cita de Joaquín de Entrambasaguas y Peña, Vida de Lope de Vega, Barcelona, Labor, 1936, p. 100. Sobre la concepción gremial del oficio por parte de los primeros autores ver Carmen Sanz Ayán y Bernardo García García, «El 'oficio de representar' en España y la influencia de la comedia dell'arte (1567-1587)», Cuadernos de Historia Moderna, 1995, 16, pp. 475-500, pp. 494-495. 
los miembros más destacados de las «compañías reales» formaban parte de unas clases medias urbanas integradas por los cuadros medios de la administración del estado, comerciantes con cierto nivel económico, artesanos de objetos de lujo y artistas de diversas disciplinas, que habían proliferado en Madrid desde principios del siglo gracias a las necesidades administrativas y suntuarias de la Corte. Todos ellos alentaban un deseo de ascenso social para sí mismos o para sus hijos, lo que les llevó - dentro de sus posibilidades- a mimetizar los usos y costumbres de la nobleza dotándose de una apariencia personal y un entorno doméstico "apropiado", hasta el punto de que en la $2^{\text {a }}$ parte de Don Quijote (p. 103) Cervantes ya señala cómo los actores «de las compañías reales y de título, que todos, o los mas, en sus trajes y compostura parecen unos príncipes».

En el caso de la profesión cómica este ascenso social se vio favorecido por la temprana consideración "artística» de su oficio pues, como señala en su Memorial de 1706 el autor y músico de compañía Juan Bautista Chavarría, «... por sí solo el ejercicio de Representante es Arte y que como tal esta admitido en la legal comprehensión de el Derecho, y de los Juristas y ejecutoriado a favor de los casos que han ocurrido...», lo que permitió al Patriarca de las Indias afirmar (1707) que «...por todos Derechos el hijo de representante, ni el que por si ha representado no está excluido, ni debe serlo de ser admitido para los empleos eclesiásticos, y seculares, honoríficos beneficios, prebendas y dignidades».

Orgullosos de su oficio, los actores de las compañías al servicio de Madrid y de la Casa Real constituyeron, pues, un grupo profesional «intelectual» bien cohesionado y con notoria influencia social, plenamente integrado dentro de una nueva clase intermedia e ilustrada para la que demostrar conocimientos artísticos era señal de prestigio, siendo la posesión de cuadros su consecuencia natural.

\section{Bibliografía}

Agulló Mercedes, «100 documentos sobre el teatro madrileńo (1582-1824) », en $E l$ teatro en Madrid 1583-1925, Madrid, Museo Municipal, 1983, pp. 85-137.

Álvarez Sellers Alicia, «Iconografía del retrato de actor: «La Calderona», «Juan Rana» y Pablo de Valladolid», en Álvarez Sellers Alicia, Del texto a la iconografia. Aproximación al documento teatral del siglo XVII, Valencia, PPU, 2008, pp. 277-320.

Arellano Ignacio (ed.), El Siglo de Oro español: texto e imagen. Navarra, Eunsa, 2011.

Armas Frederick A. de, «De Tiziano a Rafael: pinturas y libros en La Viuda Valenciana de Lope», en Lerner Isaías, Nivel Robert y Alonso Alejandro (eds.), Actas del XIV Congreso de la Asociación Internacional de Hispanistas, New York, 16-21 de Julio de 2001, 2 vols, Newark-Delaware, Juan de la Cuesta, 2004, vol.II, pp. 165-172.

Ayala Mallory Nina (ed.), Antonio Palomino. Vidas, Madrid, Alianza, 1986.

Barrionuevo Jerónimo de, Avisos (1654-1658), 2 vols. (Biblioteca de Autores Espańoles), Madrid, Atlas, 1968.

Bergman Hanna E., "Juan Rana se retrata", en Homenaje a Rodríguez Moñino, 2 vols., Madrid, Castalia,1966, vol. I, pp. 65-73. 
Bertaut Francois, Journal du voyage d'Espagne (Paris 1659), en García Mercadal José, Viajes de extranjeros por España y Portugal. Desde los tiempos más remotos hasta comienzos del siglo XX, Valladolid, Junta de Castilla y León, 1999, vol. III, pp. 391523.

Bolańos Donoso Piedad, «Antonio de Prado y su esposa Mariana de Morales (1632)», Criticón, 2007, 99, pp. 167-192.

Brown Jonathan, Velázquez. Pintor y cortesano, Madrid, Alianza, 1986.

Brunel Antoine de, Voyage d'Espagne curieux, historique et politique. Fait en l'année 1665 (Colonia, 1666), en García Mercadal José, Viajes de extranjeros por España y Portugal. Desde los tiempos más remotos hasta comienzos del siglo XX, Valladolid, Junta de Castilla y León, 1999, vol. III, pp. 253-365.

Calvo Serraller Francisco, Teoría de la Pintura del Siglo de Oro, Madrid, Cátedra, 1991.

Camón Aznar José, «Teorías pictóricas de Lope y Calderón», Velázquez, 1964, I, pp. 66-72.

Canonica Elvezio, «Lope y los literatos italianos en la corte de Felipe III», Anuario Lope de Vega, 2000, VI, 61-73.

Castro Francisco de, Primera parte de Alegría Cómica, Zaragoza, 1702.

Caturla $M^{a}$ Luisa, «El coleccionista madrileño Don Pedro de Arce, que poseyó Las hilanderas de Velázquez», Archivo Español de Arte, 1948, XXI, pp. 292-304.

Cervantes Miguel de, Don Quijote de la Mancha (Madrid, Juan de la Cuesta, 1615) (2a parte). Edición de Avalle-Arce Juan Bautista, Madrid, Alhambra, 1979.

Cotarelo y Mori Emilio, Bibliografía de las controversias sobre la licitud del teatro en España, Madrid, Tip. Rev. de Archivos, Biblioteca y Museos, 1904.

Cotarelo y Mori Emilio, Actores famosos del siglo XVII: Sebastián de Prado y su mujer Bernarda Ramírez, Madrid, Tip. Revista de Archivos, Biblioteca y Museos, 1911.

Cotarelo y Mori Emilio, «Actores famosos del siglo XVII: María de Córdoba Amarilis y su marido Andrés de la Vega», Revista de la Biblioteca, Archivos y Museo del Ayuntamiento de Madrid, 1933, X, pp. 1-33.

Deleito y Piñuela José, La mujer, la casa y la moda (en la España del Rey Poeta), Madrid, Espasa Calpe, 1946.

Diccionario biográfico de actores del teatro clásico español (DICAT), Ferrer Valls Teresa (dir), Kassel, Reichenberger, 2008.

Díez Borque José Ma , La vida española en el Siglo de Oro según los extranjeros, Barcelona, Serbal, 1990.

Díez Borque José Ma, «Literatura y artes visuales», en Díez Borque José Ma ${ }^{a}$, Verso e imagen. Del Barroco al Siglo de las Luces, Madrid, Comunidad de Madrid, 1993, pp. 251-257.

Díez Borque José Ma, «Calderón y el «imaginario» visual. Teatro y pintura», en Calderón de la Barca y la España del Barroco, Madrid, Sociedad Estatal Nuevo Milenio, 2000, pp. 195-219.

Díez Borque José Ma, Calderón de la Barca. Verso e Imagen, Madrid, Comunidad de Madrid, 2000.

Egido Aurora, La página y el lienzo: Sobre las relaciones entre poesía y pintura en el Barroco, Zaragoza, Real Academia de Nobles y Bellas Artes de San Luis, 1989. 
Egido Aurora, «Introducción» a su edición de La fiera, el rayo y la piedra de Pedro Calderón de la Barca, Madrid, Cátedra, 1989, pp. 11-121.

Entrambasaguas y Peña Joaquín, Vida de Lope de Vega, Barcelona, Labor, 1936.

Fayard Janine, Los miembros del Consejo de Castilla (1621-1746), Madrid, Siglo XXI, 1982.

Flórez María Asunción, Música teatral en el Madrid de los Austrias durante el Siglo de Oro, Madrid, ICCMU, 2006.

Flórez Asensio María Asunción, «El Coliseo del Buen Retiro en el siglo XVII: teatro público y cortesano", Anales de Historia del Arte, 1998, 8, pp. 171-195.

Flórez Asensio María Asunción, «Diego Velázquez y Cosme Pérez: Genio e ingenio en la corte de Felipe IV", Madrid, revista de arte, geografia e historia, 1999, 2, pp. 217 253.

Flórez Asensio María Asunción, «Fernández, Luisa», en Diccionario Biográfico Español, Vol. XVIII, Madrid, Real Academia de la Historia, 2011, pp. 574-575.

Flórez Asensio María Asunción, "Romero, Luisa», en Diccionario Biográfico Español, Vol. XLIV, Madrid, Real Academia de la Historia, 2013, pp. 340-342.

Flórez Asensio María Asunción, «Músicos de las compañías teatrales de Madrid ante el cambio dinástico», en Capdepón Paulino y Pastor Juan José (eds.), Sebastián Durón (1660-1716) y la música de su tiempo, Vigo, Editorial Academia del Hispanismo, 2013, pp. 307-326.

Fuentes para la historia del teatro en España I. Representaciones palaciegas: 1603-1699.

Estudio y documentos, Norman D. Shergold Norman D. y Varey John E. (eds.), Londres, Támesis, 1982.

Gállego Julián, El pintor de artesano a artista, Granada, Universidad de Granada, 1976.

Gállego Julián, Visión y símbolos de la pintura española del Siglo de Oro, Madrid, Cátedra, 1984.

García Mercadal José, Viajes de extranjeros por España y Portugal. Desde los tiempos más remotos hasta comienzos del siglo XX, Vol. III, Valladolid, Junta de Castilla y León, 1999.

García Valdecasas Amelia, "Concepción de los actores en la sociedad de la época», Diálogos Hispánicos de Amsterdam, 1989, 8, pp. 843-852.

Genealogía, origen y noticias de los comediantes de España. Fuentes para la historia del teatro en España II, Shergold Norman D. y Varey John E. (eds.), Londres, Támesis, 1985.

Inventarios reales. Testamento del rey Carlos II. 2 vols. Madrid, Museo del Prado, 1981.

Jordan William B. y Cherry Peter, Spanish Still Life from Velázquez to Goya, Londres, National Gallery Publications, 1995.

Lope de Vega, Peribañez y el Comendador de Ocaña, Marín Juan Ma (ed.), Madrid, Cátedra, 1979.

Lope de Vega, La prueba de los amigos, Gómez Jesús y Cuenca Paloma (eds.), Lope de Vega. Comedias, XIII, Madrid, Biblioteca Castro, 1997, pp. 94-193.

Lope de Vega, La viuda valenciana, Ferrer Valls Teresa (ed.), Madrid, Castalia, 2001. Lope de Vega, Arte nuevo de hacer comedias (1609), García Santo-Tomás Enrique (ed.), Madrid, Cátedra, 2006. 
López Pinciano Alonso, Philosophia Antigua Poética (1595), Rico Verdú José (ed.), Madrid, Biblioteca Castro, 1998.

López Torrijos Rosa, La mitología en la pintura española del Siglo de Oro, Madrid, Cátedra, 1995.

Marías Fernando, «Don Pedro de Arce ¿coleccionista o regatón? y Las hilanderas de Velázquez», Archivo Español de Arte, 2003, LXXVI, pp. 418-425.

Martín González Juan J., El artista en la sociedad española del siglo XVII, Madrid, Cátedra, 1984.

Memorial de Juan Bautista Chavarría, s.f. Impreso sin foliar. Biblioteca Nacional, Madrid, VE 198/91.

Memorial del Patriarca de las Indias al rey Felipe V (25-I-1707). Biblioteca Nacional, Madrid, Mss. 14004/6.

Moormann E.M., De Acteón a Zeus. Temas sobre la mitología clásica en la literatura, la música, las artes plásticas y el teatro, Madrid, Akal, 1997.

Morán Turina Miguel, «Aquí fue Troya (de buenas y malas pinturas, de algunos entendidos y otros que no lo eran tanto)», en Morán Turina Miguel y Portús Pérez Javier, El arte de mirar. La pintura y su público en la España de Velázquez, Madrid, Istmo, 1997, pp. 93-116.

Moreto Agustín, El desdén con el desdén, Rico Francisco (ed.), Madrid, Castalia, 1978.

Negredo Fernando, «El Madrid de Velázquez: mercado y propiedad inmobiliaria entre 1623 y 1650», Madrid. Revista de arte, geografía e historia, 1999, 2, pp. 15-56.

Oehrlein Josef, «El actor en el Siglo de Oro: imagen de la profesión y reputación social», en Diez Borque José $\mathrm{M}^{\mathrm{a}}$ (ed.), Actor y técnica de representación del teatro clásico español, Londres, Támesis, 1989, pp. 17-33.

Palomino Antonio, El museo pictórico y escala óptica, Madrid, 1715.

Palomino Antonio, «El Parnaso Español Pintoresco Laureado» en Palomino Antonio, El museo pictórico y escala óptica, vol. III (Madrid, 1724). En Ayala Mallory Nina (ed.), Antonio Palomino. Vidas, Madrid, Alianza, 1986.

Pérez Pastor Cristóbal, Nuevos datos acerca del histrionismo español en los siglos XVI y XVII, Madrid, Imprenta Revista Española, 1901.

Pérez Pastor Cristóbal, Documentos para la biografía de D. Pedro Calderón de la Barca, Madrid, Real Academia de la Historia, 1905.

Pérez Pastor Cristóbal, "Nuevos datos acerca del histrionismo español de los siglos XVI y XVII» (2a serie), Bulletin Hispanique, 1907, IX, pp. 360-385 y 1914, XVI, pp. 209-224 y 458-487.

Portús Pérez Javier, Lope de Vega y las artes plásticas. Estudio sobre las relaciones entre pintura y poesía en la España del Siglo de Oro, Madrid, Universidad Complutense, 1992.

Portús Pérez Javier, Pintura y pensamiento en la España de Lope de Vega, Guipúzcoa, Nerea, 1999.

Portús Pérez Javier, «Significados sociales en el bodegón barroco espańol», en García Santo-Tomás Enrique (ed.), Materia crítica. Formas de ocio y de consumo en la cultura áurea, Madrid, Universidad de Navarra-Iberoamericana-Vervuert, 2009, pp. 169-189. 
Rennert Hugo Albert, The Spanish Stage in the time of Lope de Vega, New York, The de Viune Press, 1909.

Rodrigues Vianna Peres Lygia, «El retrato y El Arte de la Pintura de Francisco Pacheco en obras del teatro del Siglo de Oro», en Mata Carlos y Zugasti Miguel (eds.), Actas del congreso El Siglo de Oro en el nuevo milenio, 2 vols., Pamplona, Eunsa, 2005, vol. II, pp. 1477-1490.

Rodríguez Cuadros Evangelina, La técnica del actor español en el Barroco. Hipótesis y documentos, Madrid, Castalia, 1998.

Rodríguez Cuadros Evangelina, "Registros y modos de representación en el actor barroco: datos para una teoría fragmentaria», en Diez Borque José Ma (ed.), Actor y técnica de representación del teatro clásico español, Londres, Támesis, 1999, pp. 35-53.

Rozas Juan Manuel, «Sobre la técnica del actor barroco», en II Jornadas de Teatro Clásico Español, Almagro, Festival de Almagro, 1979, pp. 90-106.

Ruiz Lagos Manuel, Estética de la pintura en el teatro de Calderón, Granada, Graficas del Sur, 1979.

Ruiz Lagos Manuel, «Interrelación pintura/poesía en el drama alegórico calderoniano. El caso imitativo de la Iconología de C. Ripa», Goya, 1981, 161-162, pp. 282-289.

Sáez Raposo Francisco, Juan Rana y el teatro cómico breve del siglo XVII, Madrid, Fundación Universitaria Española, 2005.

Sánchez Escribano Federico y Porques Mayo Alberto, Preceptiva dramática española en el Renacimiento y el Barroco, Madrid, Gredos, 1971.

Sánchez Jiménez Antonio, El pincel y el Fénix: pintura y literatura en la obra de Lope de Vega Carpio, Madrid, Universidad de Navarra-Iberoamericana-Vervuert, 2011.

Sánchez Jiménez Antonio, "Paralelos entre pintura y poesía durante el Siglo de Oro espańol: las poses de El Greco y Lope de Vega en la transición de artesanos a artistas», en Tietz Manfred y Trambaiolli Marcella (eds.), El autor en el Siglo de Oro. Su estatus intelectual y social, Vigo, Editorial Academia del Hispanismo, 2011, pp. 379-395.

Sanz Ayán Carmen, «Éxito y crédito: funciones del hato de una actriz en la empresa teatral áurea», en Pedraza Jiménez Felipe, González Cañal Rafael y García González Almudena (eds.), Damas en el tablado. XXXI Jornadas de Teatro Clásico (Almagro, 1 a 3 de julio de 2008), Almagro, UCLM, 2009, pp. 53-82.

Sanz Ayán Carmen y García García Bernardo J., «El oficio de representar en España y la influencia de la comedia dell'arte (1567-1587)», Cuadernos de Historia Moderna, 1995, 16, pp. 475-500.

Shergold Norman D. y Varey John E., Los autos sacramentales en Madrid en la época de Calderón, Madrid, Edhigar, 1961.

Tirso de Molina, Cigarrales de Toledo (1624), Vázquez Fernández L. (ed.), Madrid, Castalia, 1996.

Zayas y Sotomayor María de, Novelas amorosas y ejemplares (Zaragoza, 1637), Olivares Julián (ed.), Madrid, Cátedra, 2000. 
